\title{
Effect of Corporate Social Responsibility on Tax Avoidance in China
}

\author{
Tong Chen ${ }^{1}$, Maisarah Mohamed Saat ${ }^{2}$ \\ ${ }^{1,2}$ Azman Hashim International Business School, Universiti Teknologi Malaysia, \\ 81310 Johor Bahru, Johor, Malaysia \\ ${ }^{1}$ tongchen@graduate.utm.my, ${ }^{2}$ maisarahsaat@utm.my
}

\begin{abstract}
Corporate social responsibility (CSR) has aroused heated discussion in recent years. The public generally believe that the enterprises with good CSR performance will not be involved in aggressive tax avoidance issues. However, as several famous socially responsible technology companies were found to be involved in aggressive tax avoidance, the association between those two variables has been doubted. This paper analyzes the effect of CSR on tax avoidance with the evidence of Chinese listed companies from 2016 to 2020. The finding is that good CSR performance leads to an increase in effective tax rate. In other words, the higher the CSR report score, the higher tax payment and the lower tendency in tax avoidance.
\end{abstract}

Keywords: Corporate social responsibility, Tax avoidance, Organizational culture, Risk management.

\section{Introduction}

In recent years, related party transactions are becoming more and more common as the result of economic globalization, along with more complex and covert means of tax avoidance. Many multinational companies have been involved in tax avoidance scandals. In fact, it becomes normal for the enterprises to participate in tax avoidance. Since tax avoidance harms national fiscal revenue and distorts the allocation of public resources, it is necessary for tax departments to take action. Various tax avoidance methods and the huge enterprise base increase the difficulty of supervision by the tax departments. In order to solve this problem, tax departments usually use information technology to identify risky enterprises.

The enterprises that often participate in social responsibility activities can leave good records in tax departments and therefore are less likely to be marked as risky enterprises. In other words, good CSR performance is an insurance-like weapon. Most current academic articles that study the effect of CSR on tax avoidance from organizational cultural perspective support this idea. From organizational cultural perspective, good CSR performance can inhibit tax avoidance behavior. However, there is some opposition in recent years. Some scholars believe that CSR performance may be used by some enterprises to deceive tax departments so that they can carry out more aggressive tax avoidance plans? Nowadays, there is an abnormal phenomenon in the society that the enterprises with good social responsibility are often reported to participate in unethical or illegal tax activities. Thus, the effect of CSR on tax avoidance remains to be explored.

Therefore, this paper empirically studies the effect of CSR on tax avoidance. Whether good CSR performance can inhibit tax avoidance or whether CSR has been used to cover up aggressive tax avoidance will be explored. As a country with a comprehensive tax system, China is more representative when exploring the effect of CSR on tax avoidance. Therefore, this paper will be supported with the data from China.

\section{Theoretical Analysis and Hypothesis}

\subsection{Organizational Culture Theory}

Many traditional scholars supported that CSR activities are a part of organizational culture and morality. Enterprises will choose behaviors that conform to their own organizational culture and ethics in the decision-making process (Fleischer and Christie, 2009). Tax avoidance harms social interests and therefore enterprises with good CSR performance will try to avoid aggressive tax avoidance in practice. Those traditional studies support that good CSR performance inhibits tax avoidance.

Lanis and Richardson (2012) took 408 Australia listed companies from 2008 to 2009 as a sample and discovered that CSR is negatively associated with tax avoidance. Hoi et al. (2013) studied 11,006 firm-years observations from 2003 to 2009 in the United States and found that poor social responsibility performance is accompanied by lower cash effective tax rate and therefore by higher possibility to be involved in aggressive tax avoidance activities. Watson (2015) separated 7,297 firm-years observations from 2001 to 2011 in the United States into two groups and discovered that CSR is negatively associated with tax avoidance in low-earning group. López-González et al. (2019) took 6,442 firm-years international observations from 2006 to 2014 as a sample and found that the association between CSR performance and tax avoidance is negative. Besides, the negative association is less significant in family-firm group. Based on above information, this paper has made following assumption:

Hypothesis 1a: CSR has negative effect on tax avoidance.

\subsection{Risk Management Theory}

Some studies that are from risk management perspective have empirically obtained the opposite results to traditional view and believe that CSR is positively correlated with tax avoidance. 
Comprehensive risk management theory emphasizes on the integrated management of enterprise risk. The integrated management of enterprise risk refers to the identification and evaluation of all the factors affecting the value of the firm and to the application of corresponding measures throughout the firm to manage those risks (Meulbroek, 2002).

Based on risk management theory, the better the CSR performance, the better the social reputation. When enterprises are affected by negative news, the social reputation brought by good CSR performance becomes a shield against criticism and punishment. Such a shield helps to slow down the impact of the negative news on enterprises. Therefore, active participation in social responsibility activities helps enterprises improve their ability to prevent risk. Kotler and Lee (2005) found that CSR activities forms a moral shield for enterprises, which helps reduce the criticism of enterprises. Eisingerich and Preuss (2010) supported that enterprises actively participating in social responsibility activities can use CSR as a tool to mitigate the impact of negative moral news. Bhardwai (2011) also believed that in order to alleviate the public criticism and governmental punishment caused by negative news, enterprises treat CSR as a risk management tool. The conclusion that fulfilling CSR can reduce the risks faced by enterprises has been proved by many empirical results.

The reason why enterprises decide to participate in tax avoidance is that they believe the benefits brought by tax avoidance is greater than the cost, and the cost includes long-term corporate financial crisis caused by future punishment and the damage of corporate image if the tax avoidance behaviors are detected by tax departments. Therefore, enterprises will inevitably take corresponding measures to reduce those risks and CSR is a good tool to manage the risk of tax avoidance. Davis et al. (2016) used the cash effective tax rate as an indicator to measure tax avoidance and the results showed that the companies with better CSR performance have lower cash effective tax rate. Gandullia and Piserà (2020) took 15 European countries as a sample and discovered that CSR ratings are negatively associated with average effective tax rates. Based on above analysis, the following assumption has been made:

Hypothesis $1 \mathrm{~b}$ : CSR has positive effect on tax avoidance.

\section{Research Methodology}

\subsection{Sample and Data Collection}

This paper selected listed companies in Shanghai Stock Exchange and Shenzhen Stock Exchange from 2016 to 2020 as a research sample. The sample only includes A-share listed companies. CSR data were collected from hexun.com, and other data were collected from CSMAR database. To guarantee data integrity and continuity, following screening was carried out: (1) exclude the companies listed after
December 31, 2015; (2) eliminate the companies under Special Treatment; (3) eliminate finance and real estate companies; (4) eliminate the objects with missing data; (5) winsorize the continuous variables with many outliers at $5 \%$. Finally, 1,670 firm-years observations are collected, and the statistical software adopted is Stata 15.0.

\subsection{Model and Variables}

This paper focuses on analyze the effect of CSR on tax avoidance empirically by following regression model.

$$
E_{T F} F_{i, t}=\beta_{0}+\beta_{1} \operatorname{CSR}_{i, t}+\sum \beta_{2} \text { CONTROLS } S_{i, t}+\varepsilon_{i, t}
$$

\subsubsection{Dependent Variables}

The degree of tax avoidance is dependent variable. Referring to the method of Lanis and Richardson (2011), effective tax rate is used to indicate the degree of tax avoidance. Table 1 illustrated the formula.

\subsubsection{Independent Variables}

The explanatory variable is CSR. The current measurement methods of CSR in China mainly include accounting method, content analysis method and index method. Index method is one of the most widely used methods in current academic articles. The index method measures CSR from different dimensions, and the score shows CSR performance. Based on previous research, this paper uses CSR report score collected from hexun.com to measure CSR performance.

\subsubsection{Control Variables}

According to Abbott et al. (2012) and Fox and Murray (2014), this paper selects company size, debt to asset ratio, return on asset, the proportion of fixed assets, the proportion of intangible assets, the proportion of inventory, asset turnover rate, year and industry as control variables.

The variables are shown in Table 1.

Table 1: Variables List

\begin{tabular}{|c|c|c|c|}
\hline Type & Variables & Symbol & Formula \\
\hline $\begin{array}{c}\text { Dependent } \\
\text { Variable }\end{array}$ & Effective Tax Rate & ETR & $\begin{array}{c}\text { ETR = Income Tax } \\
\text { Payable / Income Before } \\
\text { Taxes; } \\
\text { Income Tax Payable = } \\
\text { Income Tax Expense - } \\
\text { Deferred Income Tax }\end{array}$ \\
\hline \multirow{2}{*}{$\begin{array}{c}\text { Explanatory } \\
\text { Variable }\end{array}$} & $\begin{array}{c}\text { Corporate Social } \\
\text { Responsibility }\end{array}$ & CSR & $\begin{array}{c}\text { Corporate Social } \\
\text { Responsibility Report } \\
\text { Score from hexun.com }\end{array}$ \\
\hline \multirow{4}{*}{$\begin{array}{c}\text { Control } \\
\text { Variable }\end{array}$} & $\begin{array}{c}\text { The Size of the } \\
\text { Company }\end{array}$ & SIZE & $\begin{array}{c}\text { The Natural Logarithm } \\
\text { of the Total Assets }\end{array}$ \\
\cline { 2 - 5 } & Debt to Asset Ratio & LEV & $\begin{array}{c}\text { Total Liabilities / Total } \\
\text { Assets }\end{array}$ \\
\cline { 2 - 5 } & $\begin{array}{c}\text { The Proportion of } \\
\text { Fixed Assets }\end{array}$ & PPE & $\begin{array}{c}\text { Net Income / Total } \\
\text { Assets }\end{array}$ \\
\cline { 2 - 5 } & $\begin{array}{c}\text { The Proportion of } \\
\text { Intangible Assets }\end{array}$ & INTAN & $\begin{array}{c}\text { Intangible Assets / Total } \\
\text { Assets }\end{array}$ \\
\hline
\end{tabular}




\section{Results}

\subsection{Descriptive Statistics}

Table 2: Descriptive Statistics

\begin{tabular}{|c|c|c|c|c|c|}
\hline Variable & Obs & Mean & Std. Dev. & Min & Max \\
\hline ETR & 1670 & 18.373 & 10.781 & -9.045 & 60.673 \\
\hline CSR & 1670 & 22.147 & 5.813 & -0.02 & 37.21 \\
\hline SIZE & 1670 & 22.996 & 1.461 & 20.043 & 28.636 \\
\hline LEV & 1670 & 43.523 & 17.711 & 3.521 & 90.507 \\
\hline ROA & 1670 & 4.516 & 2.919 & -7.606 & 11.68 \\
\hline PPE & 1670 & 22.363 & 15.867 & 0.049 & 87.583 \\
\hline INTAN & 1670 & 5.618 & 7.681 & 0 & 72.939 \\
\hline INV & 1670 & 12.07 & 9.742 & 0 & 66.382 \\
\hline ASSETTO & 1670 & 69.939 & 51.416 & 2.698 & 511.643 \\
\hline
\end{tabular}

Table 2 illustrates the general conditions of the dependent variable, explanatory variable and main control variables. It can be seen that there are 1670 observations. The average effective tax rate of the samples remains at approximately $18 \%$, which is lower than but close to the nominal enterprise income tax in China (i.e. 25\%). The CSR report score of most enterprises is not optimistic, and the average CSR only reaches to 22 (total score of 100). Debt to asset ratio of the sample is approximately 44\%; return on assets is approximately 5\%; the proportion of fixed assets is approximately $22 \%$; the proportion of intangible assets is approximately $6 \%$; the proportion of inventory is approximately $12 \%$; asset turnover rate is approximately 70 times. Those data are in line with China's national conditions.

\subsection{Regression Results}

Table 3: Regression

\begin{tabular}{|c|c|c|}
\hline \multirow{2}{*}{ Variable } & \multicolumn{2}{|c|}{ ETR } \\
\hline & (1) & (2) \\
\hline CSR & $\begin{array}{c}0.766^{* * * *} \\
(11.65)\end{array}$ & $\begin{array}{c}0.707 * * * \\
(10.52)\end{array}$ \\
\hline SIZE & $\begin{array}{c}-0.559 * * \\
(-2.29)\end{array}$ & $\begin{array}{c}-0.744 \text { *** } \\
(-2.86)\end{array}$ \\
\hline LEV & $\begin{array}{c}0.056^{* * *} \\
(2.61)\end{array}$ & $\begin{array}{c}0.052 * * \\
(2.39)\end{array}$ \\
\hline ROA & $\begin{array}{c}-1.532 * * * \\
(-11.50)\end{array}$ & $\begin{array}{c}-1.308 * * * \\
(-9.80)\end{array}$ \\
\hline PPE & $\begin{array}{l}0.016 \\
(1.00) \\
\end{array}$ & $\begin{array}{l}0.002 \\
(0.08) \\
\end{array}$ \\
\hline INTAN & $\begin{array}{c}0.108^{* * * *} \\
(3.51)\end{array}$ & $\begin{array}{c}0.059^{*} \\
(1.71) \\
\end{array}$ \\
\hline INV & $\begin{array}{l}0.046 \\
(1.44)\end{array}$ & $\begin{array}{l}0.044 \\
(1.29)\end{array}$ \\
\hline ASSETTO & $\begin{array}{c}0.024 * * * \\
(4.78)\end{array}$ & $\begin{array}{c}0.014 * * * \\
(2.67)\end{array}$ \\
\hline YEAR & $\mathrm{NO}$ & YES \\
\hline INDUSTRY & $\mathrm{NO}$ & YES \\
\hline Constant & $\begin{array}{c}15.504 * * * \\
(3.14)\end{array}$ & $\begin{array}{c}30.329 * * * \\
(4.88)\end{array}$ \\
\hline R-squared & 0.158 & 0.209 \\
\hline F-test & 38.017 & 22.492 \\
\hline Number of obs & 1670 & 1670 \\
\hline
\end{tabular}

The main goal of this paper is to test the effect of CSR on the degree of tax avoidance. Firstly, ETR, CSR and all main control variables were assigned into model (1). The regression results are listed in column (1) of the Table 3. Year and industry dummy variables were then added to previous regression, and the results are illustrated in column (2).

According to Table 3, the coefficients of CSR in both column (1) and (2) are positive and significant at $1 \%$ level. In column
(2), the coefficient of CSR is 0.707 , indicating that when CSR report score increases by $1 \%$, the ETR increases by $0.71 \%$. This indicates that the higher the CSR report score, the higher the effective tax rate and the lower tendency to avoid taxes. Therefore, Hypothesis 1a is supported.

As for control variables, all of them are significant except the proportion of fixed assets and inventory. The coefficients of SIZE in both column (1) and (2) are negative, which are significant at $5 \%$ level and $1 \%$ level respectively. It indicates that there is a negative correlation between company size and effective tax rate, i.e., larger enterprises in China are more likely to be involved in aggressive tax avoidance. The coefficients of LEV in column (1) and (2) are positive, which are significant at $1 \%$ level and $5 \%$ level respectively. It indicates that there is a positive correlation between debt to asset ratio and effective tax rate, i.e., the higher the debt to asset ratio, the more they want to maintain their good reputation and the less likely to avoid tax. The coefficients of ROA in column (1) and (2) are negative, which are significant at the level of $1 \%$. It shows that the return on assets is negatively correlated with effective tax rate, i.e., the higher the return on assets, the more the enterprise inclined to tax avoidance. The coefficients of INTAN in column (1) and (2) are positive, which are significant at $1 \%$ level and $10 \%$ level respectively. It indicates that the proportion of intangible assets is positively correlated with effective tax rate, i.e., the higher the proportion of intangible assets, the less the enterprise inclined to avoid tax. The coefficients of ASSETTO in column (1) and (2) are both positive and significant at $1 \%$ level. It shows that there is a positive association between asset turnover rate and effective tax rate. The higher the asset turnover rate, the less the enterprise inclined to avoid tax.

\section{Conclusion}

This paper attempts to test the effect of CSR on tax avoidance in China empirically. With the data from China, this study finds that good CSR performance can have an inhibitory impact on tax avoidance. To increase the credibility of the model, this study controls the year and industry after original regression and runs model again. The results once again prove that good CSR performance can inhibit tax avoidance.

This paper provides further empirical evidence for the effect of CSR on tax avoidance. Compared with previous articles, this paper has following advantages. First, the sample is more representative to explain the relationship. China is a country with comprehensive tax system and rapid economic development. In addition, this paper takes all industries except the finance and real estate industries as the sample. While many previous research focused on a certain industry, this sample is broader. Second, the selection of control variables is more reasonable. Besides main control variables, year and industry dummy variables are controlled. Therefore, the robustness of the results is higher.

\section{References}

[1] D. N. Fleischer \& C. A. Christie, "Evaluation Use: Results from a Survey of U.S. American Evaluation 
Association Members," American Journal of Evaluation, 30(2), pp. 158-175, 2009.

[2] R. Lanis \& G. Richardson, "Corporate Social Responsibility and Tax Aggressiveness: An Empirical analysis," Journal of Accounting and Public Policy, 31(1), pp. 86-108, 2012.

[3] C. K. Hoi, W. Qiang \& H. Zhang, "Is Corporate Social Responsibility (CSR) Associated with Tax Avoidance? Evidence from Irresponsible CSR Activities," The Accounting Review, 88(6), pp. 2025-2059, 2013.

[4] L. Watson, "Corporate Social Responsibility, Tax Avoidance, and Earnings Performance," The Journal of the American Taxation Association, 37(2), pp. 1-21, 2015.

[5] E. López-González, J. Martínez-Ferrero \& E. García-Meca, "Does corporate Social Responsibility Affect Tax Avoidance: Evidence from Family Firms," Corporate Social Responsibility and Environmental Management, 26(4), pp. 819-831, 2019.

[6] L. K. Meulbroek, "A Senior Manager's Guide to Integrated Risk Management," Journal of Applied Corporate Finance, 14(4), pp. 56-70, 2002.

[7] P. Kotler \& N. Lee, Corporate Social Responsibility: Doing the Best for Your Company and Your Cause, John Wiley \& Sons, Hoboken, 2005.

[8] L. Preuss, "Tax Avoidance and Corporate Social Responsibility: You Can't Do Both, or Can You?" Corporate Governance, 10(4), pp. 365-374, 2010.

[9] A. B. Eisingerich \& G. Bhardwai, "Corporate Social Responsibility: Does Social Responsibility Help Protect a Company's Reputation?," MIT Sloan Management Review, 52(1), pp. 18-28, 2011.

[10] A. K. Davis, D. A. Guenther, L. K. Krull \& B. M. Williams, "Do Socially Responsible Firms Pay More Taxes?," The Accounting Review, 91(1), pp. 47-68, 2016.

[11] L. Gandullia \& S. Piserà, "Do Income Taxes Affect Corporate Social Responsibility?," Corporate Social Responsibility and Environmental Management, 27(2), pp. 1017-1027, 2020.

[12] R. Lanis \& G. Richardson, "Corporate Social Responsibility and Tax Aggressiveness: An Empirical Analysis," Journal of Accounting and Public Policy, 31(1), pp. 86-108, 2011.

[13] L. J. Abbott, S. Parker \& T. Presley, "Female Board Presence and the Likelihood of Financial Restatement," Accounting Horizons, 26, pp. 607-629, 2012.

[14] W. F. Fox \& M. N. Murray, "Taxing the Small: Fostering Tax Compliance among Small Enterprises in Developing Countries," in Taxation and Development: The Weakest Link?, R. M. Bird \& J. Martinez-Vazquez (eds), Edward Elgar Publishing, Northhampton, 2014. 